\title{
Sahita's Performance, Satire of the Life of Javanese Women
}

\author{
Yustina Devi Ardhiani
}

The Religious and Cultural Studies Program, Sanata Dharma University Yogyakarta, Indonesia. Email: devilitto@yahoo.com

\begin{abstract}
Sahita is a performance art group established in Surakarta-Central Java with four members of Javanese women who are in their forties to fifties. On stage performance, Sahita acts upon old women who are not pretty, but plump, attractive, energic, and humorous. Their performance is considered "uncommon" considering the fact that Sahita's cultural background is Javanese which is dominated by youth, beauty, proportional body as the beauty of female bodily form, and gentle manner as women described on stage performance. The research questions highlights why Sahita prefers to have satire style and chooses traditional art as the basis in producing new works? The data are gained through field observation, deep interview and library study. The finding reveals that Sahita prefers the satire style to express what is hard to talk in the daily life and to express critics in humorous ways so that the critized party can also enjoy the performance. In their works, Sahita makes traditional art as its base because of its strong background in traditional art and because of its unlimited exploration. What makes Sahita unique besides its members who are all women voicing women's anxiety, Sahita also presents traditional art with contemporary taste in their works.
\end{abstract}

Keywords: women artists, Javanese culture, traditional art, contemporary art, satire

\section{INTRODUCTION}

"Performance art stage is my life. I am fully aware that when I grow older, all of this will end, I will no longer be able to celebrate my dancing," said a ronggeng Jaipong dancer from Kerawang-West Java, Indonesia. Similar anxiety plagues women artists especially dancers (Surur dan Anoegrajekti, 2004: 6-7). The statement portrays the perception of a ronggeng dancer that aging means the end of career as dancer. Is it true?

Discussing Javanese women in performance art stage is discussing the issue of marginalization of Javanese women. Religion, culture, and structure of Javanese society reinforce each other to limit the space for women and as consequence makes it difficult (although not impossible) to unravel and overcome. The issue of women in performance art is inseparable from the context in art which position women as passive object of art instead of subject of art capable of creation on her own will. The preconceived notion is that performance art requires young, beautiful, and sensual women as prima donna. There is also a notion that what people are looking for from female dancers is their sensual appeal sensually appealing. In addition, most female dancers accept the view that youth is an important factor for the success and sustainability of their career (Surur and Anoegrajekti, 2004: 25). 
This situation is also seen by Lindsay who explained that women in performance art in Indonesia face specific challenges mostly due to negative perception of family and society towards them. Taboos in performance art are including featuring women's body in front of live audience, committing activities in public sphere (whereas women are perceived as belong to domestic sphere), and in the evening (women working late night are often stigmatized). Due to such challenges, Lindsay sees that there are only very few women in leadership position in performance art including manager, choreographer, and director (Lindsay, 2009: 15).

Sahita, as the primary subject of this article is a performance art group established in Surakarta-Central Java. Sahita that was established in 2001, three years after the fall of the authoritarian regime of Soeharto, is one of the very few distinctive performance art groups in Indonesia. Sahita is one of few women artists in Indonesia that are able to express themselves as creator, choreographer, actor, artistic director, costume and make up director, as well as manager in their performances.

Sahita is comfortable calling themselves dance theater group. Conceptually, there is no final definition what it means by dance theatre. Sahita is comfortable with the label dance theater because in every performance, they feature elements of dance and elements of theater simultaneously. However, the label does not fully reflect the existence of the work of Sahita which place comedy as the center of their performance. Whatever name best represents Sahita's works, it is important to acknowledge that the group is exploring tradition to discover identity through performance art. Sahita offer art which revive traditional values while criticizing them. Sahita is taking the royal art form yet using the spirit of of the people/commoners (wong cilik) to voice the aspiration of women. Therefore, it is probably to label their performance as dance theater ala Sahita.

Members of Sahita are four Javanese women turning 45-56 years old this year. They are Thingthong/Sri Setyoasih (56 years old), Atik/Atik Sulistyaning Kenconosari (54 years old), Inong/Wahyu Widayati (53 years old), and the youngest one, Cempluk/Sri Lestari (45 years old). Thingthong, Atik, Inong, and Cempluk are their stage nicknames. Sahita is interesting as subject of study, because as middle-age women, they choose to present themselves as fat elderly women, a character far older than themselves. This choice is "deviant" considering that all members of Sahita are Javanese women and living in a society cherishing or even requiring youth, beauty, and proportional weight from women working in performance art. Furthermore, in performance art, stereotype of Javanese women is embodied in traditional dancer, especially royal dancers who are identical with youthful, beautiful, gentle, and submissive.

In general, this article discusses the existence of Sahita as performance art group consisting of four middle-age women, by proposing two research questions. First, why Sahita who are younger (middle-age) choose to appear in satirical manner as sassy, lively, outspoken, humorous women on stage? Second, why Sahita choose traditional art as the basis in producing new works? 


\section{Satire of Srimpi Srimpêt}

The first work of Sahita namely Srimpi Srimpêt is discussed in this article to describe idea and orientation of Sahita that they express with satire in their performances. Other works of the group will be described as far as they help explain Sahita's creative process from time to time. Srimpi Srimpêt is an interpretation of Kalatidha letter by Ranggawarsita III that organized based on the structure of classic traditional dance, the Serimpi Dance. However, Srimpi Srimpêt is different from Serimpi Dance. The following is a brief description of the opening scene in one of Sahita's appearances when performing Srimpi Srimpêt on stage of performing arts.

Dusk in the well-lit terrace of the Radya Pustaka Museum in Surakarta (October 27, 2015). The light came from the shining full moon and the lamp shot right into the area in front of the Ranggawarsita statue that functioned as the stage. The atmosphere was serene when from behind Ranggawarsita statue faint sounds of women playing Dhandhang Gula song replicates in acapella. The sound of the singing came from four Sahita personnel performing one of their works, Srimpi Srimpêt.

Accompanied with the songs, from backstage came four women with wrinkled faces, gray hair, dressed in shabby kebaya, and every time their mouths were exposed, the front teeth were dark. They walked hand in hand slowly with their body bent slightly down while carrying a roll of pandan mats and kerosene lamp. Entering the main stage, they walked to four different corners. Each turn on charcoal and kerosene in kwali (a container similar to pot without handles, made of pottery) in the four corners to shape border line of the main stage.

Listening to the sounds of song and seeing the body language, procession performed while smelling the strong sense of incense, we can see that Sahita is performing ritual to open their performance. The procession that lasted less than five minutes was able to build a serene atmosphere among the audience. However, the silence only lasted for a moment, because several seconds later bits and gags were deliberately thrown to the stage Sahita that we will never find in Serimpi performance. The silly skits they do, turning the silence into laughter. For example, Inong poked Atik's buttocks while walking in front of her and made Atik jumped in surprise scream in surprise, or, Thingthong fell down while doing certain movement requiring balance. When she fell down, shamelessly Thingthong said, "Kegeden bamper iki, mulakno tiba" [My buttocks is huge indeed, it is too big that I fell], and the audience laughed at it.

From the glimpse of the opening scene above, there are a number of striking differences between Serimpi dan Srimpi Srimpêt dance that we will explore further. As already discussed, Srimpi Srimpêt was born out of the interpretation of Sêrat Kalatidha that uses Serimpi dance as a foundation, and then creates a parody to transform the dance into a satirical work different from its basis. The definition of satire in this paper is an art of communication containing criticism and irony, created by laughing at one self that is able to entertain wider community including the subjects of criticism. Satire involves the manifestation of the three subject positions, i.e. the satirist, the audience/ readers/listeners (the satire), and the target of joke (the satirized). Hence, satire occurs when there are parties throwing jokes (satirical humor), a party that is ridiculed, and 
the object of satire/ridicule, including the satirist himself/herself (Simpson, 2003: 8, 9096; LeBoeuf, 2007: 3; Sunardi, et all, 2011: 61- 83). This paper specifically discusses the subject creating satire, namely Sahita who are the main subject of research.

The following are the differences identified between Serimpi Dance and Srimpi Srimpêt. First, Serimpi dance is generally performed as a tribute to the king, whilee Sahita creates Srimpi Srimpêt as a form of offering to the King, the Almighty, Creator of the Universe. Satire in the idea shaping the Srimpi Srimpet shows that the offerings for the Almighty can be done by anyone, including Sahita whose personnel are neither princess nor selected dancers of the palace. Sahita implicitly view that tribute to the king should also be able to be performed by ordinary people.

The second difference is that Serimpi is usually performed by four beautiful young women with proportionate posture, beautiful costume, and makeup that highlight the beauty of dancers. Meanwhile, Srimpi Srimpet is performed by four elderly unattractive women who are a little overweight who walk slowly while bending their back like true elderly women. The makeup, hairdo, and the shabby kebaya were worn by Sahita to make them look much older than they really are. Satire in this section shows that anyone can dance. Dancers do not have to be young, beautiful and have proportional posture. Sahita who is middle-aged and performed as elderly women is the evident. The shabby costumes that make Sahita's posture look increasingly fat and makeup that keeps Sahita far from being beautiful in public view do not prevent them from performing with confidence on stage.

The third difference is if Serimpi dance is accompanied by Javanese gending with a set of gamelan instruments played by a number of pengrawit (Javanese gamelan music players), Srimpi Srimpêt performance is accompanied by neither one of them. The accompaniment of the performance is an acapella performed by Sahita members who eloquently mimicked a number of gamelan musical instruments. The acapella colored the whole staging of Srimpi Srimpêt. The idea of satire shown in this section is that dancing does not have to depend on the availability of musical instruments and music players. The body is the main condition as well as tools for Sahita to produce their works which include exploration of sounds from their own mouth.

The fourth difference is if Serimpi displays the majesty of a traditional dance that comes from the palace, in Srimpi Srimpêt, Sahita actually presents the simplicity of a performance, because Sahita positioned their work as a work of ordinary people, people with almost no wealth and power, and therein the satire. Through Srimpi Srimpêt, Sahita points out that not all art work are as costly to be staged at performing arts stage.

The fifth difference is the Serimpi dance is identical with tenderness, subtlety, elegance, beauty and courtesy of the dancers, while in Srimpi Srimpêt, seen on stage are four elderly women with wrinkled faces, big posture, and uncontrollable emotions. Srimpi Srimpêt also features unregulated and fun movements that at one point seems well organized and at another point looks chaotic. If the Serimpi dancers seem reserved, Srimpi Srimpêt characters looks quite the opposite. Satirically, all of Sahita's personnel let their emotions stand out on the stage; their feeling of being constrained and limited 
by tradition, resistance against self-centered leaders, and expression of taboo topics rarely discussed such as sexuality. Sahita also explores unusual gestures prohibited to be performed by the Serimpi dancers. All of these are among the features created and performed by Sahita in Srimpi Srimpêt.

The five points above clearly demonstrates the satirical distinction between Serimpi dance and Srimpi Srimpêt. In addition, Sahita's view of the canonization issue of the performing arts, namely locating certain artworks as noble, of high quality, majestic, and must be preserved according to the party considered as the authority in the life of Javanese society (the king and royalties). One of the scenes in Srimpi Srimpêt (Sahita's performance in Solo, October 27, 2015) which shows Sahita's view on the issue of canonization of performing arts is when Cempluk forgets the lyric of a poem and makes it a joke. Responding to her mistake, Inong expressed her anger and said, "Don't you know that kagunan (culture) is noble? You shall not make joke of it and giggle about it! Kagunan is art! Get it?" Inong raised her voice while pointing towards the pandan mat instead of Cempluk. In the scene, Cempluk plays a role as one who tries to play with traditional art and her act is opposed by Inong who positions herself as guardian of tradition. Inong anger is not only aimed at Cempluk, but also towards people (symbolized with pandan mat) that are considered ignorance and unappreciative towards noble art. On the one hand, Inong represents the anger of the parties upholding tradition and preventing tradition to be treated as laughing stock. On the other hand, the satire emerges through the fact that Inong is also a part of the work that "play with" traditional art namely Serimpi Dance. The dialogue implies that Srimpi Srimpêt is a manifestation of Sahita's criticism towards the canonization of work of art, in which the value of a work is determined by the ruling parties, and the works considered noble are those produced inside the place wall and works born in the community, including the works of Sahita are less appreciated.

\section{Performing as Elderly Women, the Strategy of Sahita in their Work}

Sahita choose to look much older than their real age for several reasons. Firstly, since the beginning of their works (in 2001) the age of all Sahita personnel is not young anymore, i.e. between 29-40 years. Sahita realize that, in average, the artists (dancers or theater players) who have many opportunities to perform on art performance stage are young people. However, Sahita believe that old age is not a barrier to work. Therefore, Sahita answer the question through their works.

Secondly, Inong said (Interview with Inong, 02/27/2016), "Kula nek dandan biasa ra ana wong nggagas, dandan tuwo niku jane yo trik, ben digagas." (When I wear regular dress there is no attention, wearing an old dress is actually also a tactic, to steal an attention from the audience). It means that Sahita consciously choose the role of an elderly woman to steal the audience's attention. The awareness that all Sahita personnel is no longer young, the posture that is not slim and the skin that is not as bright as the stereotypes of beautiful women formed by the media, has encouraged Sahita to find ways to attract the audience's attention. Furthermore, presenting themselves as elderly women with solid, lively, flirty, and cheerful characteristic, has becomes their choice. 
Thirdly, Sahita choose the character and role as elderly women because it is close to the daily life of the audience. Almost certainly everyone has experienced the dynamics of life with the elderly women, and one day everyone will grow old too. The significant differences, which are at the same time become the main attraction in here, the figure of elderly women who are presented is not the figure with the stereotype found in the society. The elderly women presented by Sahita on stage was not a wise grandmother, who is calm in carrying herself, speaking softly, firmly, and wisely in giving advice. The four elderly women integrated into Sahita's appearance on stage, always look lively, cheerful, playful, expressive, have a loud tone of voice, speak out frankly and sometimes mischievous. Those behaviors of elderly women that are different from the stereotypes in the society, in general look are considered improper and the madness is presented by Sahita in a satire in their work in the stage of art performance.

Fourthly, by presenting himself as elderly women, Sahita freely talk anything to the audience who look much younger. In addition, the appearance is acceptable to the audience from all walks of life. Children, teenagers, adults, to the elderly, are attracted to the agile and stylish appearance of Sahita's grandmothers.

By appearing as elderly women, Sahita demonstrate a satire that is very close to the daily life of the community. One day all of the Sahita personnel will be as old as or even much older than their performances on stage, so is everyone watching and laughing enjoying their show. However, does the audience realize that they are laughing at people close to their lives? Does the audience also realize that they are laughing at their own "future" life when one day they will get old too? At the time Sahita perform imitation to create tragic and comedic aspects, at the same time, with the aim of attracting the audience, a satire occurs. Regardless of whether the audience is aware or not on a satire that invites their laughter, Sahita offer a spectacle that is not merely decorated with the faces of young women.

\section{Standing on Traditional Art, Looking at Contemporary Arts}

Since the first works were created, namely Srimpi Srimpêt, Sahita have used Javanese traditional arts as the foundation of their works. The experience in reviewing Serat Kalatidha, choosing the Serimpi dance as the basis for the motion and giving birth to a new work, have made Sahita rethink about the option of reinterpreting traditions. Inong said that the considerations that arise why they take the tradition as the foundation of Sahita's works,

“...kita bekal kuatnya memang tradisi, saya, Mbak Thing, Bu Atik itu semua dari ASKI dan punya pengalaman menari. Cempluk, meskipun bukan dari ASKI tetapi dia menyukai seni tradisi, suka karawitan. Nah, karena semua punya bekal tradisi dan seni tradisi tidak akan habis kalau kita gali, kami jadi mantap mengambil seni tradisi sebagai pijakan karya-karya Sahita." “... our strong foundation is the tradition, I, Mbak Thing, Bu Atik are all from ASKI and have experience in dancing. Cempluk, even though not from ASKI, she loves traditional arts, like karawitan. Well, because all of us have the basis of tradition and traditional arts never ending to explore, we are confident to take the traditional arts as the foundation of Sahita's works" (Interview with Inong, 18/09/2015). 
Prior to the establishment of Sahita, the personnel were member of Gapit Theater beginning in late 80 's. Gapit Theater is a theater group in Surakarta led by Bambang Widoyo SP who also acted as writer and director of the production of the group. The experience with Gapit and Bambang Widoyo SP whose all the manuscripts depart from the Javanese tradition with full of rude jokes, typical of suburbia, have great influence on the character of Sahita's works. In the end, the Sahita as a group agreed that they will always use the traditional arts as the basis of their works.

However, Sahita's works cannot simply be classified as traditional art because what Sahita does is using the traditional arts as the foundation of the works, and producing new works that are different from their original traditional arts. Instead, Sahita criticize the rigidity of the rules in the traditional arts where it seems that there is no opportunity for the community to be creative by using the traditional arts. Inong asserted, what Sahita are doing is trying to "bring the traditional arts to the community", in the sense of trying to make the traditional arts become increasingly known to the society, to bring them closer to the community, and to attract people to learn and develop the traditional arts (Interview with Inong, 13/10/2016).

Sahita develop the traditional arts in a way that is different from traditional art performances in general. It is the uniqueness of Sahita which deserves appreciation, because Sahita present traditional arts with contemporary taste. How are traditional and contemporary arts understood? Traditions and contemporary are understood as attitude and orientation towards time. Traditional refers to attitudes and orientations that are directed to the past (Simatupang, 2013: 161). The tradition is deeply rooted in society, constantly embedded and at the same time develops with the society which supports the tradition (Kussudiardja, 2000: 160) and by referring to things believed to have been passed down from generation to generation, in general, at least three generations (Edward Shils via Simatupang, 2013: 160).

Tradition, as stated by Giddens (1994: 63), is associated with memory (especially the collective memory), involving ritual, associated with the formulation of the idea of truth, having the keepers of tradition, and having a connection with moral and emotional content as well. The thing that also needs to be realized is that the tradition is a human activity; therefore there is no tradition that has not changed (Simatupang, 2013: 12-13, and 160).

Contemporary art is marked by a mentality in which there is no particular dominant style (Danto via Tanke, 2011: 76, 79). The understanding on contemporary arts refers to attitudes and orientations that prioritize conformity with present-day conditions (Simatupang, 2013: 161). In the arts of dance, contemporary dance is defined as a form of experimental dance that tries to find new values and expressions that are different from the forms of dance (tradition) ever existed. The form of contemporary Indonesian dance is very diverse. By looking at the process, one of the factors underlying the birth of various forms of contemporary Indonesian dance is the interaction that occurs between cultures, both local culture and between individuals representing local culture with a very close foreign culture. Various kinds of dialogue that occurs based on the spirit of freedom to create may lead to the creation of works in various forms (Murgiyanto, 2015: 84, 97, 98, and 99). 
Contemporary sense that arises in the flexibility of creating, improvising, and space which is not strictly structured may be contrary to the traditional rules presented by Sahita at the same time. The problem that often occurs when presenting traditional and contemporary art is that there is a tension between those who want to maintain the traditional arts and those who seek to develop a tradition to respond to changes (Kussudiardja, 2000: 160). In such tensional situation, how do Sahita present traditional art with a contemporary sense in their works?

Sahita present traditional art in various forms. For example, we can refer to Sahita's first work entitled Srimpi Srimpêt. This work clearly presents the traditional arts because its point of departure is from Sêrat Kalatidha containing têmbang macapat poem and the poem is sung directly by the Sahita personnel in Srimpi Srimpêt. Meanwhile, the basic motion and dramatic plot of Srimpi Srimpêt are taken from Serimpi dance to the accompanied with akapela voice of Sahita personnel mimicking the sound of Javanese gamelan. In other forms, Sahita often present rituals of sesaji which is still often conducted in Javanese traditional events. In the opening scene of Srimpi Srimpêt, Sahita perform a ritual of sesaji in which they bring klasa bangka and téplok kerosene lamp, while in Srimpi Kêtawang Lima Ganêp and Pangkur Brujul, Sahita present sesaji in the form of bancakan and jajan pasar.

Sahita's costume, makeup and hairstyles on the stage also reflect the Javanese culture. All Sahita personnel use kebaya costume, jarik fabric, and hair in a bun. In certain works Sahita use a shabby kebaya supported by makeup and hairdressing asserting them as poor, dirty, and very old village women. Sometimes, although Sahita still present themselves as old female figures, they do not look very poor because they use bright and clean-looking kebaya. The selection of costumes, makeup, and hairstyles is adjusted to the work they perform.

Shabby Jarik and kebaya cloth were formerly worn by women in Javanese rural areas and used as everyday clothing, while kebaya which look new and nice were usually used on certain feasts. In the past, only noble families or those who live close to the palace were able to wear a nice kebaya in their daily life. Nowadays only few women, both in cities and in villages, use kebaya and jarik as everyday clothing. Kebaya and jarik clothes tend to be too complicated (not practical), uncomfortable to use because it feels hot, and the users cannot move freely. Kebaya, jarik, and buns are only used in special occasions such as weddings or in certain celebrations.

In contrast to Sahita, in their hands, wearing kebaya, jarik, and buns is common, not too complicated and it does not take time. Although they dress themselves with a little help from fellow Sahita personnel, in less than an hour they can wear jarik, kebaya clothes, wearing a bun at the same time doing makeup, and ready to perform as a lively and witty aged woman. The costumes, facial and hair makeup of all the Sahita personnel that make them appear as elderly women, as if to affirm that now only old people who are still faithful to keep the tradition. The option of wearing kebaya costume and jarik, nêmbang while dancing the Javanese traditional dances, completed with sesaji in a container called tampah (although it contains jajan pasar instead of sajèn as found in sesaji in general), is sufficient to give the impression that Sahita are presenting a Javanese tradition. 
How is the contemporary aspect presented in Sahita? On the stage, the seriousness built through the mantras, songs, and dances, is often filled with movements that invite laughter. Therefore, seriousness never lasts long in Sahita's stage performances. The short seriousness and prolonged laughter become one of Sahita's peculiarities in almost every appearance. Body language, straightforwardness in dialogue, the totality of expression, and the flexibility motion of all parts of the body, are the main attraction of their appearance.

Songs presented by Sahita especially in the performance entitled Réwangan, are not pure old songs identical to the tastes of the elderly people in general, not also pure songs of young people today; Sahita combine a wide variety of songs. Sahita make a medley of songs that incorporate folk songs, songs in Bahasa Indonesia, and songs in English. What Sahita present on the stage shows that they emphasize the flexibility, free creativity and improvisation, not strictly structured, and it can be combined with various forms of accompaniment.

The implementation of contemporary performing arts is also carried out by Sahita with stage settings that facilitate communication with the audience. The stage is set so as the players can enter from different directions, from the stage, from below the stage, or from the audience, and they can communicate with the audience. Sahita's ability to build communication with the audience becomes one of its strengths. In almost all the performances, Sahita try to bring the audience to the stage, take the audience up on the stage, or the personnel step down to the audience. Often, the distance between the stage and the audience is barely visible when Sahita begins to mingle with the audience, sometimes they even remove the boundary between the audience and the players. When the boundary between audience and players almost does not exist, sometimes a chaos occurs that blurs the whole staging. In such situations, Sahita immediately withdraw from the middle of the audience, and re-place themselves on stage.

By observing the appearance of Sahita, on the one hand, Sahita present a tradition with certain rules of the game. On the other hand, they deliberately present the flexibility of expression which, in turn, contradict the rules of the tradition they perform at the same time. Therefore, Sahita's works cannot simply be categorized as a work of contemporary art and also cannot simply be regarded as a traditional art, but it is a work of art that blends the traditional and contemporary arts. Sahita as an art group is among the dynamics of social life of society. They are not only colored by the traditional and contemporary arts, but both traditional and contemporary arts also color Sahita's creative process in their works. Sahita's uniqueness that deserves appreciation is their ability to compose classical, traditional, and contemporary arts in a dance theater work in performance arts stage.

\section{CLOSING}

Sahita offer a performance that does not only combine the traditional and contemporary arts, but also criticizes social issues. Sahita voice the hearts of women who made the audience laugh and think about what is being laughed at. Sahita's jokes do not demean women but instead increase the self-esteem of women. 
The most basic thing that Sahita does is to provide a performance that invites people to recognize themselves so as they dare to be themselves, where Sahita strive to make their works on the arts performance stage be a mirror of life that presents a performance as well as guidance. Thus, Sahita's existence deserve to be maintained and fought for not solely because all the personnel are women, but they has become a working space for women who are able to create on the basis of the desires of the women themselves.

The closing question is: how is Sahita's sustainability in the future? Until now, Sahita have not yet prepared an embryo that someday, when Sahita have no longer be possible to be on the stage, is expected to replace them. If there is no regeneration, undoubtedly what happens to Gapit will also happen to Sahita. Therefore, the hard homework for Sahita is to think and prepare young women performers who are interested, capable, and willing to be Sahita's successors. ${ }^{* * *}$

\section{BIBLIOGRAPHY}

Giddens, Anthony. 1994. Living in a post-traditional society. In Ulrich Beck, Anthony. Giddens and Scott Lash, Reflexive modernization: Politics, tradition and aesthetics in the modern social order, 56-109. Cambridge: Polity Press.

Hatley, Barbara. 2009. Tubuh perempuan, teks, dan gerakan sosial. Jurnal Perempuan 62: 48-57.

Kussudiardja, Bagong. 2000. Bagong Kussudiardja: Dari klasik hingga kontemporer. Yogyakarta: Padepokan Press.

LeBoeuf, Megan. 2007. "The power of ridicule: An analysis of satire". Senior Honors Projects, Paper 63. http://digitalcommons.uri.edu/srhonorsprog/63 (accessed June 01, 2012)

Lindsay, Jennifer. 2009. Perempuan dalam seni di Indonesia: Sebuah pengantar. Jurnal Perempuan 62: 15-22.

Murgiyanto, Sal. 2015. Pertunjukan Budaya dan Akal Sehat. Yogyakarta: FSP-IKJ, Komunitas Senrepita.

Simatupang, Lono. 2013. Pergelaran: Sebuah mozaik penelitian seni-budaya. Yogyakarta: Jalasutra.

Simpson, Paul. 2003. On the discourse of satire: Towards a stylistic model of satirical humour. Amsterdam/Philadelphia: John Benjamins Publishing Company.

Sunardi, St., G. Budi Subanar, A. Supratiknya, Timbul Haryono, Siswadi, Djohan Salim, Ki Udreka, and Hanggar Budi Prasetya. 2011. Ki Hadi Sugito: Guru yang Tidak Menggurui. Yogyakarta: BP ISI Yogyakarta.

Surur, Miftahus dan Novi Anoegrajekti. 2004. Politik tubuh: seksualitas perempuan seni. Jurnal Srinthil 6: 5-27.

Tanke, Joseph J. 2011. "What is the aesthetic regime?" Parrhesia: A Journal of Critical Philosophy No. 12: 76-79, http://www.parrhesiajournal.org/about.html (accessed April 10, 2014) 